\title{
Assyria in Early Modern Historiography
}

\author{
Dr Jennifer Sarha
}

When Sir Walter Ralegh wrote about ancient Assyria in his History of the World in 1614, he quoted a Roman author from the second century CE. Knowledge about Assyria in the early modern period was derived from two sources: the Bible, with its scattered references to Assyria as an enemy of the Israelites, and the classical corpus. Among Greek-writing historians, Assyria is mentioned briefly by Herodotus and Plutrach, with more extensive treatments in Athenaeus, and Diodorus Siculus. Justinus, the aforementioned Roman, was the primary Latin source for later historians from Orosius (fourth century CE) to Charles Rollin (1734-38). The narrative concerning Assyria is centred around two notorious royal figures: Queen Semiramis, who dressed as a man, conquered many lands and built the walls of Babylon, and died after attempting incest with her son, and King Sardanapalus, who dressed as a woman, hid in his palace, and died by setting himself on fire after losing his kingdom to Arbaces the Mede. Until the nineteenth century, writing history about ancient Assyria involved the transmission, sometimes word for word, of this basic narrative.

The historiography of this practice in the early modern period is both complex and unstudied. Engaging with Greek and Roman texts was a crucial part of Renaissance humanism, and Assyria formed part of the classical tradition thus received and created. Semiramis and Sardanapalus belonged to the cultural landscape of writers such as Aristotle and Cicero, and their place as signifiers for Assyria was disseminated to early modern Europe along with the classical corpus. The varying trends of historiography in Western Europe - medieval chronicles, antiquarianism, national histories based on Livy and political histories based on Thucydides, investigative inquiries à la Lorenzo Valla - would have exerted pressure on writing history about Assyria, despite its limited pool of texts and its lack of corroborating physical evidence. The history of Assyria at this point is a resolutely textual tradition; unlike ancient Rome, evidence of which could still be found all over Europe, Assyria did not have a material past until the nineteenth century. While not all historians used archaeological artefacts in their inquiries, there was a growing paradigm of antiquarianism within historiographical culture from Petrarch's observations on 
Roman ruins onwards.1 For Assyria, this would have aligned the production of historical knowledge as an exercise in mythography, closer to locations such as Amazonia rather than the verifiable Greece or Rome. Moreover, the historiography of Assyria would also have been informed by the exemplary traditions around both Semiramis and Sardanapalus. Their names were deployed to debate questions of gender hierarchy, revealing a tendency to insert their acts of crossdressing and their ways of gaining and losing power into political arguments. Assyrian history in the early modern period was written, read, and used with an eye on multiple historiographical paradigms, and often with specific rhetorical and moralising aims.

This chapter aims to shed light on the problematics of Assyrian historiography; specifically, to explore the strategies used to produce historical knowledge about Assyria through Semiramis and Sardanapalus. In post-medieval Europe, Assyria held a pervasive albeit lightly-spread role, and much further research is needed to understand the complexity of its presence in different cultures and languages, its discursive functions in exemplary tropes, and its positioning and usage within the competing paradigms of biblical and classical authority. My inquiry, focusing on the use of classical sources to construct knowledge about Assyria specifically, knowledge that was viewed as valid according to contemporary historiographical trends as well as corresponding to contemporary concerns about gender and power - aims to shed light on a crucial part in the reception of Assyria before the birth of archaeological Assyriology: the ways in which knowledge about Assyria was conditioned by the classical tradition and its centralising of Semiramis and Sardanapalus.

My study is centred on three authors/texts; spanning 250 years, several languages and cultural contexts, all widely read, with influence and audiences outside their specific genres. Giovanni Boccaccio's De Casibus Virorum Illustrium (13601373) and De Mulieribus Claris (1361-62), written in Latin for a literate royal court at Naples, establishes the status of Semiramis and Sardanapalus in late medieval Europe before the proliferation of accessible translations of Diodorus, Plutarch, and Herodotus, in the Renaissance. Johann Carion's Carionis Chronicon and its later 
rewritings by Philip Melanchthon, composed in Latin for a sixteenth-century protestant readership in Wittenberg, provide information on the positioning of Assyria in the early modern conceptions of universal history, particularly in the Protestant millenarian tradition. By examining the alterations between the two texts, it is possible to explore the reception of specific classical authors as well as the rising influence of humanist rhetoric on Assyrian historiography. Finally, Walter Ralegh's History of the World, (1614, London, English) tells us about writing Assyria at a time when investigative strategies and causality had become the mainstay of historiographical practice. While the selection of texts here studied comprises genres with varying relationships to historical accuracy, they all contain narratives which aim to provide historical "truths" and deploy historiographical strategies to do so: using sources considered creditable, but also interrogating and evaluating those sources in order to produce a persuasive argument. The treatment of Semiramis and Sardanapalus allows for an investigation into the main challenges of producing historical knowledge about Assyria as well as a review of the longevity and panEurope scope of this tradition. In order to put it in context, however, it is first necessary to explain how knowledge about Assyria was acquired in antiquity: how was the tradition of knowledge received in late medieval and early modern Europe created?

Assyria as Transmitted Knowledge

Ancient Assyria, located broadly in modern Iraq, was both a well-functioning state with a comprehensive administrative system and an expansionist empire in continuous warfare with its neighbours. It held influence as far as modern Cyprus and Armenia as well as locally. From the second millennium to the seventh century BCE, it competed for hegemony with Hittites, Egyptians, Medes, Elamites, and above all Babylonians, Assyria's nearest rival in both culture and politics. During the NeoAssyrian period (911-612 BCE), it aimed to extend its yoke further over the Levant, including Israelite and Egyptian territories.2 The reign of Assyria's last great king, 
Ashurbanipal (c. 669-630 BCE) included successful campaigns against Egypt, Elam, and Babylon, annexed to Assyria since 745 BCE. After Ashurbanipal's death, Assyria fell into decline and was defeated in 612 BCE by a combined army of Medes and Babylonians. All this is known to us because of nineteenth-century archaeological excavations; modern Assyriology rests on the discovery of cities such as Nineveh, whose administrative records et al had survived in the form of clay tablets, and the subsequent deciphering of cuneiform. Prior to these discoveries, however, what was known about Assyria was based on the textual remnants of two hostile, and in the case of the classical corpus of Greek and Roman writers, remote cultural traditions.

The biblical tradition on Assyria is mainly concentrated on the Neo-Assyrian period, particularly Assyrian military expansion in the second half of the eighth century and its sudden downfall in 612.3 Isaiah 1, the main Biblical source on eightcentury BCE Assyria, describes the military might of the Assyrian army, but credits its success to the designs of the Hebrew god. The Book of Nahum takes a similar approach to the fall of Nineveh (ostensibly presented as a prophecy written in advance of the event, but most likely composed during or after).4 For biblical writers, Assyria is an enemy whose history provides a satisfying arc; from initially oppressive victories over the Israelite peoples to an ignominious defeat. It is also worth highlighting the use of gendered language; Cynthia Chapman has shown that biblical books tend to discuss Assyria as a sexualised (masculinised) threat to the femalegendered Jerusalem, only to be defeated by the even more (and correctly) masculinised Hebrew god.5 There is a tension between the competing masculinities of Assyria and Israel, which is negotiated through an overt and excessively sexualised portrayal of Assyria and predicated on concepts of unlawful abuse. For later Assyrian historiography, this provides a conceptual foundation, but less in the line of useable details.

The Greek tradition on Assyria, also the basis of the later Roman tradition, has a more complex history of transmission. Assyrian sources rarely mention Greeks, which suggests, as Amélie Kuhrt has argued, little direct contact between the

\footnotetext{
3 For Assyria in the Bible, see Peter Machinist, 'Assyria and Its Image in the First Isaiah', Journal of the American Oriental Society, 103:4 (1983), pp. 719-737.

4 John R. Huddlestun, 'Nahum, Nineveh, and the Nile: The Description of Nineveh in Nahum 3:8-9', The Journal of Near Eastern Studies, 62:2 (2003), 97-110 (107).

5 Cynthia R. Chapman, The Gendered Language of Warfare in the Israelite-Assyrian Encounter (Winona Lake, Indiana: Eisenbrauns, 2004), passim.
} 
Assyrian empire and the Greek-speaking peoples of the eastern Mediterranean.6 The earliest references to Assyria in Greek sources occur in Phocylides (sixth century BCE), who notes that Nineveh had been foolish to grow so large. 7 News about the fall of Assyria would have reverberated across the Mediterranean, but it is likely that Greek conceptualisations of Assyria were informed by their interactions with Persians, with whom both Greeks and Assyrians had direct contact. The lack of contact did not, however, indicate a lack of interest. Hellanicus of Lesbos, an older contemporary of Herodotus, wrote a now-lost history of Assyria, which was still read in the second century CE. 8 Herodotus declared his intention to write a second history dedicated to Assyria; whether this intention was serious, or actually implemented, is a matter of debate.9 The most influential Greek source on Assyrian history was the Persika of Ctesias (fourth century BCE), now lost except for a few fragments.10 Ctesias served as a source for several later writers such as Diodorus Siculus (first century BCE, Greek-speaking Sicily), and Justin who in the second century CE wrote an epitome of the first-century BCE historian Pompeius Trogus (Latin-speaking Gaul).11 The wide chronological and geographical scope of Ctesias' readers (he was known by Photius in eighth-century Byzantium) indicates the influence and popularity - as fabulous tales of the East - of Persika.

Ctesias' history, as far as it has been recovered through later writers, centres around Semiramis and Sardanapalus, who serve as both bookends and counterpoints in a narrative that corresponds neatly to Assyria's expansion and fall. Nevertheless, it is worth highlighting that Persika does not reflect actual events in Assyrian history, nor can Semiramis and Sardanapalus stand for the historical Shammuramat and Ashurbanipal.12 While a transmission is likely - the story of Ashurbanipal's war with

6 Amélie Kuhrt, 'Greek Contact with the Levant and Mesopotamia in the First Half of the First Millenium BC: A View From the East', in Greek Settlements in the eastern Mediterranean and the Black Sea, ed. by G. R. Tsetskhladze and A. M. Snodgrass (Oxford: Archaeopress, 2002), pp. 17-25. 7 Anthologia Lyrica Graeca, ed. by Ernestus Diehl (Lipsiae: B. G. Tebneri, 1925), p. 48.

8 FGrHist 93 F1.

9 Robert Drews, 'Herodotus' Other Logoi', The American Journal of Philology, 91 (1970), pp.181-191. 10 Jan Stronk's recent edition of Ctesias counts 29 surviving lines. Jan P. Stronk, Ctesias' Persian History: Introduction, Text and Translation (Wellem Verlag: Dusseldorf, 2010), p. 2.

11 The extensive debate over Ctesias's recoverability is beyond my remit. Most recent research has argued, contra nineteenth-century critics such as Felix Jacoby, that Diodorus, Athenaeus, and others do in fact contain the composition of their named authors. See Dominique Lenfant, Ctésias de Cnide: La Perse, l'Inde, autres fragments (Paris: Belles Lettres, 2004); Stronk; Robert J Gorman and Vanessa B Gorman, Corrupting Luxury in Ancient Greek Literature (Ann Arbor: University of Michigan Press, 2014). 12 For the origins of the names, see Stephanie Dalley, 'Semiramis in History and Legend: a Case Study in Interpretation of an Assyrian Historical Tradition', in Cultural Borrowings and Ethnic 
Babylon was still being told in Aramaic in fourth-century BCE Persian-occupied Egypt -there is no evidence to suggest any correlation between their biographies.13 Recent studies of Ctesias assume that his sources were Persian, but how he interacted with them is not recoverable.14 What has been noted is Ctesias' conceptualisation of the ancient Near East as infested with gender trouble.15 Assyria is presented as a site where norms of gender and hierarchy are disrupted; it expands its territories because a woman usurps a man's position and male clothes, and comes to ruin because a man adopts a woman's life. This framing would have conditioned the ways in which knowledge about Assyria was repeated; in the Greek-speaking world Semiramis and Sardanapalus were used in debates about rightful rule and justified deposition. Aristotle mentions Sardanapalus as a monarch dethroned because of contempt: 'somebody killed Sardanapallus when he saw him combing wool with his women', followed by a suggestion that if this was not true of Sardanapalus, it was true about somebody.16 In the Nicomachean Ethics Aristotle associates Sardanapalus with a life of unthinking enjoyment, like that of cattle.17 Cicero, in Tusculan Disputations, repeats this association, and in Letters to Atticus, uses his name for a man who prefers to die on his couch.18 In On the Consular Provinces, Cicero calls a misbehaving military commander a 'Semiramis', with implications of murder and corruption, while Plutarch claims that Semiramis was a concubine who tricked her way into power, even if elsewhere he follows Ctesias' version of the story.19

This would have been the classical tradition received by late medieval and early modern writers. There were, nevertheless, differences between the narratives told by Diodorus and Justinus, and their respective histories of transmission and popularity varied considerably. Justinus remained the main source throughout the Middle Ages; over 200 manuscript copies of the Epitome survive, compared to eight of Diodorus. Justinus was not a prestigious author, but his relatively simple Latin made him useful as a teaching aid, and this ensured widespread, if not always

\footnotetext{
Appropriations in Antiquity, ed. by Erich Gruen (Stuttgart: Steiner, 2005), pp.11-22; Eckart Frahm, 'Images of Ashurbanipal in Later Tradition', Eretz-Israel, 27 (2003), pp. 37-48.

13 S. P Vleeming and J. W. Weselius, Studies in Papyrus Amherst 63: Essays on the Aramaic Texts in Aramaic/Demotic Papyrus Amherst 63 (Amsterdam: Juda Palache Instituut, 1985), pp. 31-37.

14 Stronk, p. 17.

15 Lenfant, p. cxxxv.

16 Aristotle, Politics, 5.13.

17 Aristotle, Nic. Eth. I. V.3.

18 Cicero, Letters to Atticus, 10.8.7.

${ }_{19}$ Cicero, On the Consular Provinces, 4; Plutarch, Amatorius 9.
} 
acknowledged, influence. Diodorus was better known in the Greek-speaking east, but he became more widely known after Poggio Bracciolini's Latin translation of 1449 (printed in 1472). The transmission, reception, and redeployment of Assyrian history is conditioned by the narrowness of its textual tradition - two sources, both broadly following the same narrative. Their treatment in different cultural contexts allows us to examine how historical knowledge is produced under multiple ideological frameworks, such as faith in the authority of the ancients, early modern Christian morality, and "universal" norms of gender and power.

\section{Giovanni Boccaccio}

Giovanni Boccaccio (1313-1375) wrote about Assyria in two compendiums of famous lives: De Casibus Virorum Illustrium (1360-1373) and De Mulieribus Claris (1361-62). Like his immediate predecessor Petrarch, Boccaccio wrote in a hagiographic tradition according to which the lives of saints were to inspire holy living; both Petrarch and Boccaccio applied this didactic approach to non-holy historical figures. Petrarch chose his exemplars from Greek and Roman history, but Boccaccio's reach extended from the Bible to his own contemporaries. In such a conception of world history, the value of a historical figure lies less in explicating their immediate historical context than in illustrating universal truths about the world. Boccaccio's sources on Assyria would have suggested a similar view: for Justinus, Orosius, and Diodorus (partly excerpted in Eusebius), all writing universal histories, the aim was to demonstrate the truth of certain moral beliefs, and the whole of the known world was available for this purpose. This would have differed from the views of other universal historians like Polybius, for whom a longitudinal scope was useful for explaining the succession of empires.20 For Boccaccio, historical figures provided an opportunity to write quasi-scandalous narratives in the guise of moral exhortation. What separates Semiramis and Sardanapalus from the others is the strict textual tradition from which they originate, and the way this enables Boccaccio to use 
fictionalising strategies while nevertheless producing historically-informed and authoritative knowledge.

On Semiramis, Boccaccio's treatment of classical sources combines the faithful repetition of sentences with amplification, re-alignment, and strategic juxtapositioning. The structure from Justinus:

Semiramis did not dare entrust the throne to an immature boy, but no more would she openly occupy it herself. The many great nations of their empire had barely submitted to Ninus, a man; much less would they submit to a woman. She pretended, therefore, to be the son of Ninus rather than his wife, a boy rather than a woman.21

Boccaccio rewrites this with an emphasis on Semiramis's agency and sagacity. Instead of 'not dare entrust' ('neque... ausa tradere'), we have Semiramis considering, 'existimans', the consequences of entrusting the empire to a young boy.22 In Justinus, Semiramis's accession is conveyed through a series of consequently arranged facts (her lack of daring, her unruly kingdom, her act of disguise), but Boccaccio incorporates her daring ('auderet'), and renders this an active moment: she 'was possessed of so courageous a spirit that she, a woman, dared undertake with skill and intelligence the rule of those nations which her fierce husband had subjugated and controlled with force of arms'.23 Such additions and amplification imbue Semiramis with motivations and agency; her narrative grows in dynamic tension without losing its status as transmitter of historical information.

Moreover, Boccaccio is here applying a medieval exegetic practice, enarratio. It entailed, as Rita Copeland has shown, paraphrasing and rewriting the text to explicate its 'truth for the contemporary reader'.24 There is a truth to be found in Semiramis; from Justinus's 'magnas deinde res gessit', she does great things,

21 J. C. Yardley, Justin: Epitome of the Philippic History of Pompeius Trogus (Atlanta: Scholars Press, 1994), p. 15.

22 Giovanni Boccaccio, Tutte le Opere, ed. and trans. by Vittore Zaccaria, 12 vols (Milan: Arnaldo Mondatori Editore, 1967), IX, p. 32.; Otto Steel (ed) M. Juniani Justini Epitoma Historiarum Philippicarum Pompei Trogi (Stuttgart: Tebner, 1972), p, 4. I am grateful to Dr Alex Millington for his help with Latin translation.

${ }_{23}$ Giovanni Boccaccio, Famous Women, trans. by Virginia Brown (Cambridge, MA: Harvard University Press, 2003), p. 4.

24 Rita Copeland, Rhetoric, Hermeneutics, and Translation in the Middle Ages: Academic Traditions and Vernacular Texts (Cambridge: Cambridge University Press, 1991), p. 70. 
Boccaccio draws out 'She energetically took up the royal power...she preserved both kingship and military discipline while accomplishing many great deeds worthy of even the most powerful men', which in turn allows him to argue that 'it was almost as if she wanted to show that spirit (animus), not sex, was needed to govern'.25 Boccaccio is careful about not awarding this argumentative design to Semiramis herself; rather, it is a discovery by Boccaccio. His rewriting of Justinus's narrative has enabled him to reveal this new truth - reveal, not invent - and to suggest that the received tradition on Assyria requires amplification in order to constitute 'truth'.

Furthermore, this is a truth with potential applications; a truth about the world rather than just Semiramis. The conclusion of Boccaccio's narrative, again borrowed from Justinus, is structured to undermine Semiramis's great deeds through the regrettable flaw which all women share: ungovernable lust. On this question Boccaccio turns from Justinus to look for more salacious details in Orosius: her use of her own soldiers and their murder in her hands.26 Her incest with her son is mentioned along with several other vaguely sourced sexual debaucheries, introduced by 'they say' and 'others however write'. 27 Collating sources without deciding between them was a feature in medieval chronicles - Caxton in Recuyell of the Historyes of Troye (1474) argues that it need not matter that different authors have said different things, as long as the moral point is agreed upon.28 Yet in Boccaccio, this shift from a univocal narrative to several possible sequences of events, explained through unnamed (possibly invented) sources, also takes place at the fault line of Semiramis's received reputation: when the Semiramis of great deeds becomes a woman whose low morals occasion her downfall. Boccaccio inserts multiple sources in order to detail these, and whether they were invented or not matters less than the apparent need for their inclusion, and its effects. Boccaccio does not question the veracity of any of his authors, but by presenting them cumulatively he provides this aspect of his narrative with authority as a historically-informed text. Where the first part relied on his close reading of Justinus, the second part is founded on a recognisable practice of contemporary historiography, and if the content of his sources is variable, the overall

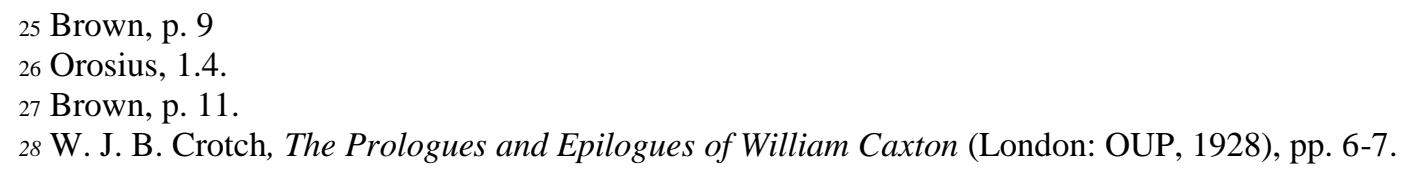


moral is very clear. This second approach forms the backbone of his reading of Sardanapalus.

Boccaccio introduces Sardanapalus still blackened with smoke; an allusion to his notorious death on a pyre, which suggests that Boccaccio expects his readers to recognise the context.29 This kind of referentiality is a key discursive strategy in Boccaccio's Sardanapalus. His readers would have known Sardanapalus from Justinus, but probably also through his exemplary usage in Aristotle and Cicero. Boccaccio creates a trajectory between familiar concepts and pure invention, which re-frames the received narrative to highlight Sardanapalus's vices. These are worth looking at some of these in detail, since Boccaccio adds several new points to Sardanapalus's existing list of debaucheries. His pleasure-seeking is expanded to include the invention of several new delights, including wine made without pressing and the canopy bed.30 His withdrawal from the sight of other men, a crucial part of the narrative, becomes a withdrawal from worthy men: Sardanapalus makes friends with butchers, fishmongers, and pimps.31 His sexual proclivities, borrowed from Diodorus through Eusebius, involve immersing himself with concubines in lasciviousness, but Boccaccio also adds that he will not provide any details, since that truth should only be expressed in the middle of pimps and prostitutes.32 This recalls a similarly suggestive idea in Dante's The Divine Comedy, where Sardanapalus knows 'what might be done behind closed doors' - evidently Sardanapalus in late medieval Italy had a reputation as someone whose actions were too naughty to be disclosed.33 Boccaccio's additions, which constitute a considerable departure from his sources, nevertheless match what his readers might expect; again, in order to produce the recognised truth about Assyria some amplifications are required.

Crucially, they match what is said by Aristotle in Politics and the Nicomachean Ethics, and repeated by Cicero in Letters to Atticus and Tusculan Disputations (all included in Boccaccio's library): that Sardanapalus lost his throne because he was caught spinning, that he lived a life of unexamined pleasure like an ox.34 The key part of the Sardanapalus legend for Aristotle and Cicero is his self-

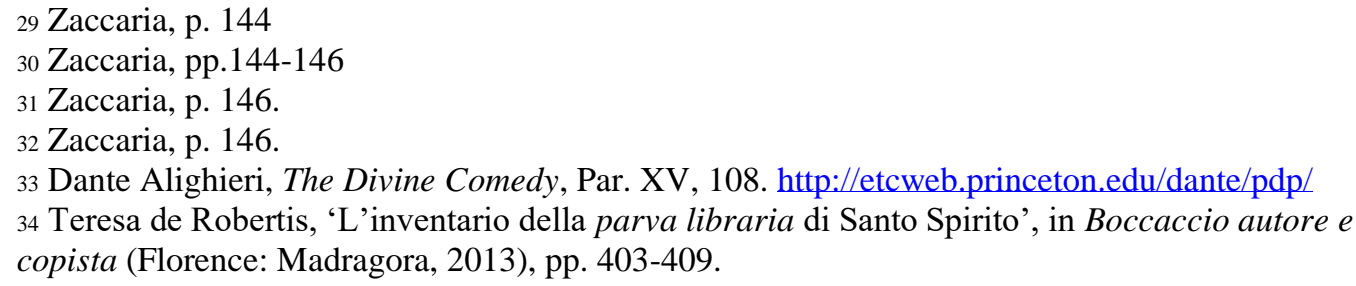


indulgence: his problematized gender performance is one aspect of it, but not its central feature. Neither Aristotle nor Cicero mention Sardanapalus's crossdressing, and Boccaccio, while clearly condemning Sardanapalus on gendered grounds, nevertheless refrains from dressing him in women's clothes. 35 Boccaccio does follow Justinus in concluding with 'et sic qui vixerat mulier, a Fortuna adversa visitatus, homo succubuit', thus one who had lived as a woman, having been visited by adverse Fortune, fell as a man - but for him Sardanapalus's crucial flaws are excessive ornamentation and abandonment of his duties. 36 This becomes the argument for Sardanapalus's deposition: in Justinus, Sardanapalus's crossdressing is intolerable to his general Arbaces; in Boccaccio, his self-indulgence is intolerable to Fortune, who then inspires Arbaces to gain sight of the King's activities. By re-structuring the narrative to include the hand of Fortune, Boccaccio underlines the moral applicability of the Sardanapalus legend - he becomes a warning example for princes everywhere.

This moral paradigm informs Boccaccio's amplifications on Sardanapalus's death. In Justinus, Sardanapalus first hides, then leads out a small army, and finally withdraws to his palace and sets himself on fire. 37 In Boccaccio, Sardanapalus is momentarily roused/excited (expergefactus) to be leading an army consisting of pimps and drunkards whose chatter causes him to imagine himself as Jupiter facing the Giants.38 He is defeated, and then hides in his palace. At this point Boccaccio introduces a moment of self-realisation: 'longi ignavique soporis postremo torpedine pulsa oculos mentis aperuit', finally, having pushed through the lethargy of a long idleness, he opened the eyes of his mind. 39 There is a lesson here: even after a reign of indolence and turpitude it is possible to 'exuta muliebri anima, virileum induit', exit the spirit of a woman, and assume manhood.40 The moral and thus historical truth concerning Assyria is always about gender trouble.

Boccaccio's treatment of Semiramis and Sardanapalus tells us something about discursive practices in late medieval Italy; that amplification and enarratio constitute appropriate responses to classical sources, and narratives can be re-aligned to discover a currently relevant moral. As the key strands of Assyrian history, they tell

\footnotetext{
35 Zaccaria's Italian translation replaces 'muliebri anima' with 'l'abito di donna'. pp. 152-153.

36 Zaccaria, pp. 152, 148.

37 Yardley, p. 16

38 In Zaccaria's Italian, this is translated as impaurito, frightened, p. 151; Zaccaria, p. 150.

39 Zaccaria, p. 150.

40 Zaccaria, p. 150. In Zaccaria's Italian this is 'toltosi l'abito di donna', removed the habit of a woman. p. 153.
} 
us something more. The conceptualisation of ancient Assyria was predicated on the classical tradition, but this involved casual references as well as the longer historical narratives - Boccaccio prioritises the ideological framework of Aristotle and Cicero over Justinus even as he is mining his work for structure and events. Semiramis and Sardanapalus had a popular reputation which had to be incorporated into their narratives. Yet the history in Justinus which provides the basic plot are nevertheless also transmitted - the narrow textual tradition which constitutes Assyrian history makes repetition of the main points easy, and even necessary; when what is known about Assyria is very little, this little must be repeated when telling the history of Assyria, and telling this little is enough to constitute the history of Assyria.

\section{Johannes Carion and Philip Melanchthon}

The publication of Poggio Bracciolini's Latin translation of Diodorus (1472) and Musurus's edition of Athenaeus (1514), brought about a considerable expansion in the classical knowledge available on Assyria. While some parts of Diodorus had been previously known through Eusebius, his full-length narratives of Semiramis and Sardanapalus provided new details. Athenaeus, although mainly repeating information familiar from Justinus and Diodorus, offered specifics as well as the names of unfamiliar classical scholars such as Duris. These additions to the existing corpus created a new challenge for writers concerned with Assyria. The rise of humanistic studies in the early Renaissance saw a change in both the demographic of reading audiences and their expectations on what they read - there was clearly a market for vernacular editions of exotic narratives from the ancient Near East. Poggio's Diodorus went through multiple editions despite its many acknowledged flaws, and served as a source for several vernacular translations (English 1487, Tuscan 1526, French translation 1535).41

The cultural context in which historical knowledge was produced was also in flux. The proliferation of newly discovered ancient texts, the emergence of both popular and scholarly print culture, and the intellectual practices associated with Italian humanism, all had a profound influence on early modern historians using

41 A complete Greek edition was published in 1559 by Henri Estienne. 
ancient sources. In 1440, Lorenzo Valla's historical analysis of the Donation of Constantine allowed him to discredit papal claims over secular authorities as well as to display his intellectual skills for both profit and glory. Valla went on to popularise a form of scholarly exegesis which interrogated ancient texts for verifiable information about the past, and provided a model for accruing fame through attention to little-known texts.42 Such interpretive strategies could be applied to the production of historical knowledge as well as its assessment. Leonardo Bruni's History of the Florentine People (1449) applied Livian and Thucydidean models of causal history to the recent past; instead of the cumulative model inherited from medieval chronicles, his history constituted an inquiry which incorporated archival records as well as chronicles.43 A historian's duty was still to provide useful exemplars for moral action, but in order for them to be useful, they must also be true.44 For Assyrian history, these developments offered a changed landscape of knowledge production, but while the strategies for writing history had increased, the materials from which information could be sought were still limited. Justinus was the most popular source, but rarely credited by historians; possibly his version was so ingrained as general knowledge that no citation was thought necessary, and it is worth keeping in mind that medieval habits such as grammatical exegesis through paraphrasing and explication continued to play a role in educational practices.

Johann Carion (1499-1537), a German historian and astrologer to the Elector of Brandenburg, wrote a universal history in 1531 which he sent to Philip Melanchthon (1497-1560) for publication.45 The extent of Melanchthon's editorial input in the Chronicon Carionis remains unclear, but he was viewed as the main author during the sixteenth century, and it is likely that the two further editions (1558 and 1560) were mostly his work; certainly we can assume that they reflect views he considered acceptable.46 The original German text was translated into Latin in 1537 by Hermann Bonnus with multiple reprints, and into English in 1550 by Gwalter Lynne. The Chronicon Carionis was a foundational text in Protestant universal

\footnotetext{
42 For Valla's influence on scholarly practices, see Anthony Grafton and Lisa Jardine, From Humanism to the Humanities: Education and the Liberal Arts in Fifteenth-and Sixteenth-Century Europe (London: Duckworth, 1986), pp. 81-89.

43 Eric Cochrane, Historians and Historiography in the Italian Renaissance (Chicago: University of Chicago Press, 1981), pp. 3-9.

44 Cochrane, p. 4.

45 Asaph Ben-Tov, Lutheran Humanists and Greek Antiquity: Melanchthonian Scholarship between Universal History and Pedagogy (Leiden, 2009), p. 37.

46 Ben-Tov, p. 37.
} 
historiography; it reflects what Asaph Ben-Tov has described as the conceptual framework of 'the unfolding and gradual revelation of God's will from Creation to the ever immanent Last Judgement' .47 Its treatment of Assyrian history, and the variations between the different editions and translations, allows us to consider both the transmission of information concerning Semiramis and Sardanapalus, and its interaction with a key facet of biblical historiography; the Four Monarchies theory posited by the Book of Daniel. Based on an interpretation of a dream by the prophet Daniel, this theory predicts the rise and fall of four great monarchies, and provided a useful paradigm for Protestant, particularly millenarian, historians.48 The history of Assyria (often placed first, and followed by Media/Persia, Greece/Macedonia, and Rome), as presented in both the biblical and the classical traditions, was easily enveloped into this paradigm. Although the Four Monarchies theory was rarely mentioned explicitly around Semiramis and Sardanapalus, it served as one of the conceptual frameworks through which Assyrian history was articulated.

The first Chronicon Carionis follows Justinus in presenting Semiramis in the context of Assyrian history; she is preceded by Ninus and followed by Ninias and Sardanapalus. This is a brief narrative, including only her rule after her husband's death, her crossdressing, and her success as a ruler: she excelled in heroic acts, 'excellevit factis plane heroicis', and reigned happily, 'imperavit feliciter'.49 While the specifics of Semiramis's crossdressing follow Justinus, there are no references to her sexual behaviour. The Semiramis who emerges from this text is an uncontroversial figure - her crossdressing made unproblematic by reasonable excuses, her incest omitted, and her successful rule praised. This excision goes against the common knowledge regarding Semiramis, by now familiar from both Justinus and Orosius as well as Poggio's translation of Diodorus. Perhaps Carion considered it irrelevant for his overall argument; his Semiramis serves primarily to introduce an inquiry into the succession of Assyria and Babylonia.50 It may also be that Carion declined from presenting a female regent in a negative light; Mary of Hungary had served as regent of the Spanish Netherlands for her brother Charles V, the Holy

\footnotetext{
47 Ben-Tov, p. 7.

48 For overview, see W. Stanford Reid, 'The Four Monarchies of Daniel in Reformation Historiography', Historical Reflections, 8(1) 1981), pp. 115-123.

49 Johannes Carion, Chronicon Carionis correctum \& emendatum (Frankfurt: Petrus Brubach, 1546), p. 14.

${ }_{50}$ Carion, p. 14. The text uses variously imperium (empire or command), monarchia, and regnum (reign/kingdom), but at this point monarchia is preferred.
} 
Roman Emperor, who was also the overlord of Carion's employer.51 By comparison, Thomas Lanquet's An Epitome of Chronicles (1549), based on Lynne's translation of Carion, incorporates both the reveal of Semiramis's crossdressing and her sexual proclivities from Orosius, and produces a heavily gendered and problematised history of Assyria.52

For Carion, however, the main purpose of Assyria was to establish a chronology among the various ancient Near Eastern states.53 He employs evidence from the Bible as well as figures such as Metasthenes and Bion. These are authors who survive only in fragments - in Metasthanes's case, in a fragment invented by Annius of Viterbo, whose works included forgeries of known but lost classical sources. Although Annius was no longer a credible source in the mid sixteenth century, his additions to the accepted canon were nevertheless occasionally used, as studies by Anthony Grafton have shown.54 These references to minor figures instead of, say, Diodorus or Plutarch, suggest that the text was claiming intellectual authority in the Italian humanist mode - we know that Melanchthon viewed humanist scholarship as a valuable addition to the Protestant intellectual movement.55 The effect this produces is not unlike the cumulative addition of unassessed sources in medieval historiography - multiple authors, regardless of their origin, provide extra authority.

Carion's Sardanapalus follows immediately his Semiramis, and is presented as a history of the fall of Assyria. He is introduced with a focus on the partition of ancient Near Eastern kingdoms: 'nobis de Sardanapalo pauca dicenda, quomodo exutus sit regno suo, \& quo postea divisa sint Imperia', we must speak a little of how his reign ended and afterwards the empire was divided.56 The moral baggage of Aristotle and Cicero -recently repeated by Erasmus in his Colloquies (1526) -

\footnotetext{
51 For contemporary debates on the regency of Mary of Hungary, see Sharon L. Jansen, The Monstrous Regiment of Women: Female Rulers in Early Modern Europe (Basingstoke: Palgrave Macmillan, 2002), pp. 98-105. While Europe at this time had no ruling queens, female regents had been a common occurrence in recent years (Anne of France, Margaret of York).

52 For Lanquet's debt to Carion, see Lily B. Campbell, Shakespeare's Histories: Mirrors of

Elizabethan Policy (London: Methuen, 1964), p. 37.

53 Carion, p. 14.

54 Anthony Grafton, 'Invention of Traditions and Traditions of Invention in Renaissance Europe: The Strange Case of Annius of Viterbo', in The Transmission of Culture in Early Modern Europe, ed. by Anthony Grafton and Ann Blair (Philadelphia: University of Pennsylvania Press, 1990), pp. 8-38; 55 James Michael Weiss, 'Erasmus at Luther's Funeral: Melanchthon's Commemorations of Luther in 1546', The Sixteenth-Century Journal, 16 (1985), pp. 91-114.

${ }_{56}$ Carion, p. 15
} 
becomes here a maxim about God: 'Quoties punire vult mundum Deus, principes impudicos donat', when God wants to punish the world, he provides shameless princes.57 As evidence to support this idea, Carion reminds us that all histories agree ('ex histories constant') on Sardanapalus's activities and offers a brief outline: he neglected his rule and gave himself to voluptuousness by painting his face and dressing as a woman.58 It is reasonable, therefore, that he should lose his throne: 'Quomodo quaeso huiusmodi Imperium calamitosum exitum non recepisset?'59 How should such an empire not receive a calamitous end? Yet there is no dramatisation of the scene where Arbaces gains sight of Sardanapalus; Arbaces is only mentioned as the ruler of Media after Sardanapalus's death. Carion is not interested in narrative dynamics - the purpose of Sardanapalus is to establish chronology and illustrate moral maxims, and for this purpose, the basic premise from Justinus is sufficient.

The 1531 Chronicon Carionis constructs a history of Assyria as a key site within universalist chronology. Debates about gendered rule are ignored in favour of establishing the precise order in which command passed from Assyria to Babylonia. A crucial point for Carion seems to have been illustrating the hand of Providence, for which the narrative of Sardanapalus's downfall in particular included relevant material. He seems also to have offered an opportunity for displaying scholarly erudition; Carion's narration of Sardanapalus's famous death by fire is brief, but he does include some extraneous details about Sardanapalus sending his sons away to Nineveh, for which he cites the historian Duris.60 Most ancient sources would place Sardanapalus himself at Nineveh, the capital city of Assyrians, and the only exception is in Athenaeus, whose Sardanapalus also sends his children to Nineveh, and who also mentions Duris as a source. 61

The 1558 edition of Chronicon Carionis presents a very different history of Assyria. Ninus built Nineveh, and held power over both Nineveh and Babylon; Semiramis was his wife, who built the walls of Babylon, cared for its ditches, and occupied many regions.62 This truncated account excises her crossdressing, her independent rule, and the praise she was accorded in the first edition of the

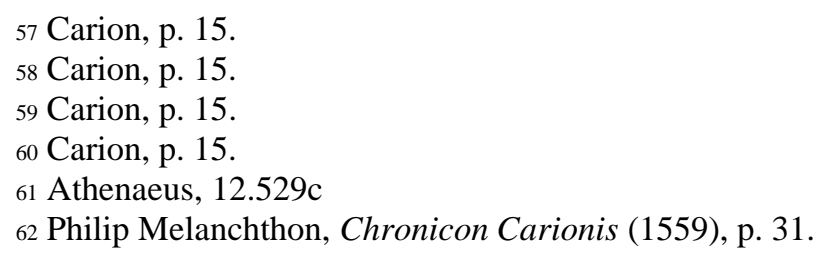


Chronicon. In 1558, the question of female rule was a topic of much contentious debate in Europe, and it appears that Melanchthon chose not to engage. The text keeps, however, Semiramis's building works in Babylon - perhaps an attempt to subsume the rule of Babylonia under the Assyrian monarchy within the Four Monarchies framework.63 Semiramis herself receives less attention than her son Ninyas who, according to Melanchthon, lived in indolence, and is used for dating Abraham. After Ninyas, Melanchthon inserts a brief interlude concerning Sodomites and the variations between the reigns and falls of Assyria and Babylonia - it is not uncommon to include a statement regarding the unknown rulers between Ninyas and Sardanapalus (this can be found in both Diodorus and Eusebius), but in Melanchthon this space of historical lacunae is filled with the 'varias mutationes' of Chaldean and Assyrian kingdoms.64

The history of Sardanapalus follows a similar pattern. He is introduced as the last to hold the monarchy of both Babylon and Nineveh.65 He is known, Melanchthon claims, because his vices distracted him from his kingdom.66 He is therefore able to evidence a maxim regarding the fall of the lofty: 'Tolluntur in altum, ut lapsu graviore ruant', those who have been raised to heights, by a heavy fall will be ruined.67 The focus is on Sardanapalus's end, and while Melanchthon does reference his vices (painting his face, immersing himself in obscene delights) and connects them explicitly (propterea) to Arbaces's rebellion, these aspects of the narrative are given comparatively little attention.68 Melanchthon nevertheless finds space for a different extraneous detail from Duris: Sardanapalus's palace burned for fifteen days.69 The section ends with a moral: 'Hic tristis exitus ad exampla irae Dei pertinet, mutantis Imperia propter principum \& populi delicta', this sad ending extends to an example of God's wrath, and the changing of command through the vices of princes and peoples.70 The history of Assyria is thus a prime opportunity to view the hand of Providence; it is a country of unworthy men, whose only merit is in enabling the establishment of chronology for the ancient Near East.

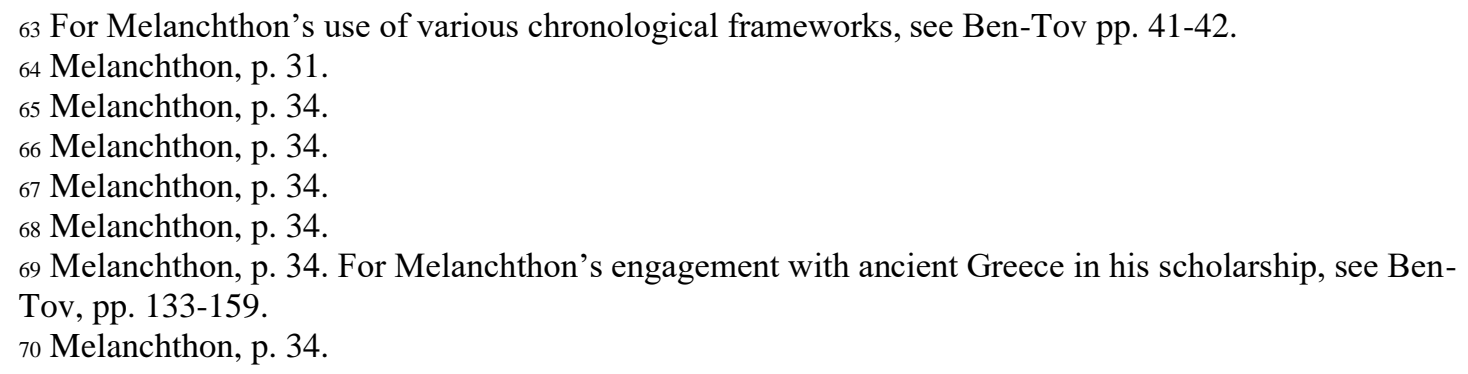


In the history of Assyria in the Chronicon Carionis, events are lifted from classical sources and positioned in the continuum of Providential history; logical inquiry is subordinated to providing the truth about scripture. Engagement with Justinus et al is minimal - neither text alters or adds to the original material, but rather information is extracted from its location, repositioned within a different universal historiographical framework, and made to serve as evidence in a new argument. This argument is constructed through reference to authorities, uncontroversial maxims about the lechery of princes which contain the rhetorical power of the commonplace, the Four Monarchies superstructure within which the rise and fall arc of Assyria fits neatly, and the weight of moral exhortation brought on by Sardanapalus's reputation. Assyria here is more concerned with its worthless men than with the unquestionably (in this text) successful Semiramis. There is little apparent interest in debating the problematics of gendered rule; unlike Boccaccio, the Chronicon Carionis offers no examination of motives or causality, and unlike Lanquet, there is no taste for repeating the sensational excesses from Orosius. This re-alignment of the conceptual baggage of Semiramis and Sardanapalus testifies to the argumentative command in Carion's historiography - their signification in both their classical and early modern articulations is subsumed to the need to discover Providence in history.

\section{Sir Walter Ralegh}

Sir Walter Ralegh's The History of the World, written during his long imprisonment in the Tower provides a final study on the problematics of Assyria in historiography. Like Carion's Chronicon, the History is a universal history with a providential framework. Ralegh's teleological approach, however, did not veer towards the hopeful ending promised in Daniel's Four Monarchies theory; rather, he espoused a view of history in which the hand of God exposes (and punishes) the failures and weaknesses of men. He also had access to a wider range of sources - Nicholas Popper has shown that Ralegh made use of texts Latin, English, French, Spanish, Italian, and Greek - to draw on for his project.71 For Assyria, Ralegh named an unprecedented 
number of authors, adding Plutarch, Herodotus, Strabo, Berossus, Arrian, and Duris to the usual Justinus and Diodorus. This is less a display of humanist erudition than an opportunity to demonstrate desirable professional skills in textual analysis and logic. The competencies derived from reading and writing history could be used to produce and strengthen political arguments; William Sherman has shown how John Dee, an older contemporary of Ralegh, deployed specific writing strategies as 'marketing ploys' to make himself more appealing to potential employers. 72 Popper suggests that for Ralegh, the chronological narrative of a universal framework offered an opportunity to highlight his skills: expertise in managing historical information should evidence 'his prudence and of divine approbation, thus persuading his sovereign to accept his counsels'.73

Writing about Assyria, however, offered particular challenges. Despite the increase in texts providing historical knowledge about Assyria (compendiums, political treatises, and histories both modern and ancient), Assyrian history continued to consist of the basic premise set down by Justinus and Diodorus. For a writer looking to establish himself as an innovative critic, this offered limited space to manoeuvre, but also a narrative arc that was increasingly widely known. The now widespread moralising discourse around Semiramis and Sardanapalus would have provided an interpretive grid, which every writer would be expected to reproduce. A further complication was occasioned by the increased popularity of Diodorus. He was the earliest surviving historian to have written on Alexander the Great, and also offered information on ancient Persia, which countered and supplemented Xenophon and Herodotus.74 Yet Diodorus's writings on Assyria constituted an intervention in the earlier tradition: his Semiramis crossdresses only to remain unmolested during her campaign, while his Sardanapalus indulges himself in not only wearing female clothes and spinning, but also in sex with men as well as women. He is, moreover, a successful military commander, who leads his army against the rebels and defeats them in three battles before being overcome by an ill-timed flood. It is worth noting that Carion chose not to engage with Diodorus, although Poggio's translation would have been available. Yet for Ralegh, ignoring Diodorus would not have been an

\footnotetext{
72 William H. Sherman, John Dee: The Politics of Reading and Writing in the English Renaissance (Amherst: The University of Massachusetts Press, 1995), p. 124.

73 Popper, p. 28.

${ }_{74}$ For early modern English interest in ancient Persia, see Jane Grogan, The Persian Empire in English Renaissance Writing, 1549-1622 (Basingstoke: Palgrave Macmillan, 2014).
} 
option - by 1614 several vernacular translations had been published, and Diodurus was frequently used by contemporary writers. Nevertheless, reconciling Diodorus's account of Semiramis and Sardanapalus with the received tradition of Justinus and his followers required a certain amount of historiographical ingenuity.

Ralegh's approach to Semiramis combines the chronological narrative with a historical investigation, which enables him to assess both his sources and the plausibility of events. It also allows Ralegh to expand on the basic plot, to reconfigure the morality of the received tradition, and to demonstrate his erudition. The narrative thus proceeds through inquiry; authors are presented, their theories examined and mostly rebutted. That Semiramis took the throne after her husband's death is agreed, but her crossdressing in pursuit of this goal is debated. Ralegh does not mention Diodorus's view, but rather quotes Justinus in that Semiramis 'presented herself to the people in the person of her son... who bore her external form and proportion without any sensible difference'.75 The logic behind this is stated as improving her chances of taking on the role 'without murmur or offence'.76 Yet this report is, in Ralegh's view, feigned. Semiramis ruled for so long, and 'performed all those memorable acts which are written of her by the name of Semiramis', and her challenge to the king of India is subscribed by her.77 Even if her son had looked sufficiently like her to allow for impersonation, it would have been impossible to maintain this for forty-two years. It is, however, possible that Ninias enjoyed a lazy life and allowed his mother to rule in his stead.

As an inquiry, this is inconclusive. Ralegh takes one of the best-known aspects of the Semiramis legend, then discredits it through logic while also offering a suggestion which allows this theory to stand - without facts having been established, the focus remains on the investigation, not the events. He also presents himself as someone who can comment authoritatively on multiple sources - Justinus here is an author whose authority is easy to discredit. Diodorus, in turn, serves to qualify Plutarch's account of Semiramis's accession, Berossus to expand on Semiramis's birth, and Jerome and others to support a learned digression on whether the Philistine fish-god Dagon was based on the Greek Triton.78 Inserting extraneous information 
was a tactic used by Carion and Melanchthon as an opportunity to quote minor sources, adding details which were not necessary for the argument, but which confirm the status of the text as containing historical information. For Ralegh, however, these authors serve to undermine the verifiable tradition on Semiramis - they advance neither the chronological narrative nor the historical inquiry.

Ralegh's treatment of Semiramis's sexual proclivities follows a similar pattern; discrediting through logic, then a digression with a plethora of sources.

But her pedigree I leave it to the Assyrian heralds: and for her vicious life I ascribe the report thereof to the envious and lying Grecians. For delicacy and ease do more often accompany licentiousness in men and women, than labour and hazard do. And if the one half be true which is reported of this lady, then there never lived any prince or princess more worthy of fame than Semiramis was, both for the works she did at Babylon, and elsewhere, and for the wars she made with glorious success. 79

Ralegh presents a maxim and goes on to provide proof of Semiramis's great deeds. Her building works in Babylon link her to a construction famous from both biblical and classical traditions. Her successful wars create a sound basis for her characterisation as an active person. Here Ralegh is ready to offer some apparently verified information: Semiramis's public deeds and her praiseworthy rule. This, coupled with the elision of all her gender troubles, constitutes a decidedly noninterventionist intervention in contemporary debates over gender and power. Female crossdressing in Ralegh's England had two conceptual currencies: young ladies dressing up as young men for love and profit on the stage (performed nevertheless by actual young men), and the occasionally ferocious debate over 'man-like' fashions. 80 These concerns would have been part of a wider continuum of anxieties regarding gender identity and costume, yet Ralegh makes no argument for or against crossdressing, merely notes it would have been unlikely for Semiramis.

79 Ralegh, p. 122.

80 Stephen Orgel argues that James I's famous admonition for London clerics to preach against certain unfeminine fashions is less concerned with ladies' use of masculine accoutrements than with low-born women imitating their betters. Orgel, 'Insolent Women and Manlike Apparel', Textual Practice 9 (1995), pp. 5-25 (p. 13). 
Her chastity, however, is insisted on. Unlike Boccaccio, who uses Semiramis's incest to re-configure his argument, or Carion and Melanchthon, who avoid the topic entirely, Ralegh raises the question but dismisses it as lies. As Judith Richards has shown, sixteenth-century accounts of Semiramis position her debaucheries as her crucial flaw - she was available as a defence of women's ability to wield power and as an exemplar of lustfulness.81 Both Mary and Elizabeth Tudor were explicitly framed as spared from this usually dominant female trait by their chastity, inviting comparisons with such chaste heroines as the biblical Deborah. 82 In Ralegh, the issue is buried under a lengthy list of evidence of her praiseworthy activities and a digression on the number of her troops, thus allowing Ralegh to avoid a discussion over a female monarch's sexuality. 83

For Sardanapalus, Ralegh creates a narrative incorporating both Justinus and Diodorus, which is deployed through a uniform authoritative voice. Unlike for Semiramis, this is neither an amalgamation of diverse sources (Ralegh names only a few) nor an inquiry with explicit historiographical analysis, but rather a deposition. Sardanapalus is introduced with a gendered insult: 'a most luxurious and effeminate palliard he was, passing away his time among strumpets, whom he imitated both in apparel and behaviour.' 84 While 'effeminacy' had been part of Sardanapalian discourse since Boccaccio, Ralegh's additions of 'palliard' and 'strumpets' imply venal lechery as well as inappropriately performed masculinity. His treatment of Diodorus consists of paraphrases, on which a gendered judgement is superimposed. Where Diodorus in Poggio's translation speaks of 'concubines' (pellicis), Ralegh uses 'strumpets' and 'harlots', neutral terms replaced with derogatory ones. 85 This interpretive grid creates a spectacle of Sardanapalus, whose gender disruption leads to justified revolt. Arbaces's discovery of Sardanapalus in women's clothes is crucial for the narrative in Justinus, while Diodorus, although he includes the scene, refrains from connecting it to Arbaces's decision to revolt.86 Ralegh prefers Justinus, but also adds to it. In Justin:

81 Judith Richards, 'To Promote a Woman to Beare Rule: Queens in Mid-Tudor England', The Sixteenth-Century Journal, 28:1 (1997), pp.101-121.

82 Richards, p. 115, 120.

83 Ralegh, p. 122.

84 Ralegh, p. 319.

${ }_{85}$ Diodorus Siculus, Diodorus of Sicily, trans. by C. H. Oldfather, 10 vols (London: Heinemann, 193367), I, p. 427; Ralegh, p, 319.

86 Yardley, p. 16; Oldfather, p. 427. 
On seeing this, Arbactus was incensed that so many warriors were subject to such a 'woman' and that men who bore swords and armour served someone who worked with wool.87

In Ralegh:

[Arbaces] was so incensed with that beastly spectacle, of a man disguised in womans attire, and striving to counterfeit a harlot, that he thought it a great shame to live under the command of so unworthy a creature. 88

Ralegh's Sardanapalus is a construction of impeccably authoritative sources, positioned to illustrate the expected moralising message. Ralegh's amplifications, nevertheless, suggest a need to heighten this condemnation. Diodorus's Sardanapalus is for Ralegh logically inconsistent: 'neither did his carriage in the beginning of that war answer to his retiredness'.89 This aspect of the narrative was a source of discomfort for many writers: Louis Leroy in his De la Vicissitude (1575) otherwise repeats Macault's 1535 translation of Diodorus word for word, but at this stage, changes to Justinus. Ralegh also rewrites the war to highlight Sardanapalus's losses: betrayed by Bactrians, his troops slaughtered in the middle of a celebratory feast, Sardanapalus was forced to withdraw to Nineveh where he was besieged for two years, and eventually killed himself.90 In Diodorus, this is a dramatic narrative, but in Ralegh a summary with a satisfying conclusion of Sardanapalus's ignoble end.

Ralegh's treatments of Semiramis and Sardanapalus differ considerably; the first is an investigation, in which the received tradition is examined for plausibility, the second a reaffirmation of the received narrative which also adds extra weights of condemnation on certain aspects of the narrative. Ralegh's account exemplifies the challenges of writing Assyrian history: the limited textual material requires (but also inspires) discursive agility in order to produce something new. The narrative imperatives, which govern re-tellings of Semiramis and Sardanapalus, require each 
story to provide a morally satisfying conclusion. The necessity of condemning discrepancies in gendered logic reveals the tension between authoritative sources - as with Semiramis's incest, for example - and the intellectual wriggling required to show that this could not be so.

Ralegh's Semiramis and Sardanapalus also tell us about the status of Assyria as a knowable historical site. The chronological trajectory of the book situates them at some distance from each other; instead of a unified history of Assyria, as in Justin, Diodorus, and Carion/Melanchthon, we have insertions of Assyria into a world history. This extractability, while reasonable in Ralegh's historiographical framework, was also a common practice in early modern uses of Assyria (as well as the classical corpus more widely).91 What Ralegh aims to do, however, is to produce new knowledge through his assortment of materials. Elizabeth Spiller has argued that cultural practice in early modern England distinguished between the 'making' of knowledge in literature and science and 'the truth ascribed to theology'.92 In Ralegh's Assyria, we can see evidence of both: the history of Semiramis is an inquiry, while Sardanapalus continues to be a legend, inviting explication but impermeable to analysis.

Writing the history of Assyria in the early modern period follows a pattern: the historical content (narrative structure, events) is taken from two classical sources, Justinus and Diodorus, whose accounts of Semiramis and Sardanapalus constitute the received wisdom concerning the history of Assyria. The reception of these tales is further informed by another strand of the classical tradition, derived from Aristotle and Cicero, which directs early modern writers to reproduce the history of Assyria as a depository of specific moral lessons. Both figures are used to demonstrate universal "truths" about gender, but there is also a consistent variation in their treatment. Boccaccio seeks motivations and causality in Semiramis, but overloads Sardanapalus with invented sins; Carion and Melanchthon repeat Justinus on Semiramis, but attach

91 For extractability of classical antiquity, see Ann Moss, Printed Commonplace-Books and the Structuring of Renaissance Thought (Oxford: Clarendon Press, 1996).

92 Elizabeth Spiller, Science, Reading, and Renaissance Literature: the Art of Making Knowledge, 1580-1670 (Cambridge: Cambridge University Press, 2004), p. 4. 
moral maxims to Sardanapalus to re-configure his narrative; Ralegh interrogates Semiramis' sources, but imposes a sexually charged interpretive grid for Sardanapalus. As Timothy Hampton has shown, the efficacy of an exemplar was dependent on the extent to which the narrative feeding it corroborated its meaning - it appears that the "truth" about Sardanapalus was particularly problematic and required extra work.93

Assyria's role in the classical tradition is a key feature in the development of its historiography. While early modern debates over Herodotus and Thucydides would have had few applications to Assyria, it is worth remembering that the rediscovery of Greek and Roman historians did not only include studies of investigative inquiry; that transmission occurred also through the dogged repetition of a received tradition. 94 Although Justinus and Diodorus formed part of the classical corpus, they were not seen as authors who inspired excitement over their beautiful phrasing, their philosophical acumen, or their spirit of historical inquiry. Alongside the wit of Cicero, the wisdom of Aristotle, and the investigative insights of Polybius or Thucydides, Justinus and Diodorus provided texts whose value lay elsewhere: in "exotic" tales of the East or a universalist approach claiming to contain all of history, with the easy extractability which this enabled. No humanist would take credit for having read Justinus, but every schoolboy knew him from their Latin lessons (passages from Justinus's Sardanapalus could still be found in Latin primers in the eighteenth century).95 Diodorus was printed and reprinted in numerous vernacular translations, and he was read as a purveyor of entertaining fabulous stories - François I included him in his travel library. The place of Assyria in the classical reception was constituted by differently valued strands of the corpus; the historical information from "middlebrow" writers like Justinus and Diodorus, and the guide for interpreting them from the more respected Aristotle and Cicero.

This premise has subtle yet powerful effects on the historical knowledge production concerning Assyria. The narrow pool of sources creates its own limitations, and the pervasively reiterated tradition which grows up around it produces

93 On the expected conformity between exemplars and their narratives, see Timothy Hampton, Writing from History: The Rhetoric of Exemplarity in Renaissance Literature (Ithaca and London: Cornell University Press, 1990).

94 Armaldo Momigliano, The Classical Foundations of Modern Historiography (Berkeley: University of California Press, 1990), pp. 51, 36, 44.

95 John Mair, An introduction to Latin syntax: or, an exemplification of the rules of construction (Edinburgh: Ruddimans, 1750) 
a cultural framework for Assyria which is dependent on both the repetition of certain narratives and the need to evidence certain universalist "truths" about the world. As we have seen, writers can and will deploy a variety of historiographical strategies for arriving at this truth, but the end result - much like the pool of sources - is always the same. This dependency on reiterating received knowledge in order to produce an authoritative argument is, as several chapters in this collection suggest, a common trend in writing about the ancient Near East.96 Yet the reception of Assyria was not complicated by encounters with contemporary peoples (unlike the Persians or the Egyptians) nor by the presence of possible archaeological remains (unlike Persia or Babylon) - in the early modern period "ancient Assyria" was entirely a textual construction. The backbone of Assyrian historiography is predicated on both the assessment and the production authoritative texts and, crucially, on the anxious repetition of their content, even if reformulated to fit what the author deems to be the truth of the narrative. What the transmission of knowledge regarding Assyria allows us to do is to consider how history can be written when both the starting point and the conclusion of the narrative are predetermined - not by historically plausible events, but by the gendered logic of the cultural framework of its historiographical tradition. 